\title{
The Effect of Price Reduction on Consumer's Buying Behavior in the U.S. Differentiated Yogurt Market
}

\author{
Rezgar Mohammed ${ }^{1}$, Olga Murova ${ }^{2}$ \\ ${ }^{1}$ Senior Lecturer, Department of Animal Production, University of Duhok, Chanden Street 1, Sumail-Duhok 1063BD, \\ Kurdistan Region, Iraq. \\ ${ }^{2}$ Associate Professor, Department of Agricultural and Applied Economics, Texas Tech University, 301D Agricultural \\ Sciences Building, Lubbock, TX, USA 79409-2132.
}

Correspondence: Rezgar Mohammed, Senior Lecturer, Department of Animal Production, University of Duhok, Chanden Street 1, Sumail-Duhok 1063BD, Kurdistan Region, Iraq.

Received: December 20, 2018

doi:10.11114/aef.v6i2.3891

\begin{abstract}
Accepted: January 7, $2019 \quad$ Available online: January 24, 2019
\end{abstract}
URL: https://doi.org/10.11114/aef.v6i2.3891

\begin{abstract}
Although price reduction is an interesting topic in marketing literature and has studied in numerous papers, less attention is paid to its effect on consumer behavior. This paper analyzes the effect of the price promotion on consumer's behavior in terms of the percentage of buying and the brand loyalty in the U.S. differentiated yogurt market. This paper tries to answer the following questions. Is the choice of high preferred brands sensitive to the price promotion of less preferred brands? Are there loyal consumers in the yogurt market? How sensitive is the consumer loyalty of high preferred brands to the price promotion of less preferred brands? Results show that a unit increase in the frequency of price reduction of less popular brands will decrease the consumer's choice of high popular brands significantly. Switching across brands is very common and there are less loyal consumers in the yogurt market where main brands have collectively only $12 \%$ loyal consumers. Loyalty of high popular brands is also sensitive to the price promotion of less popular brands as a unit increase in the frequency of price reduction for less preferred brands will decreases the share of households who are loyal to high popular brands of General Mills and Danone.
\end{abstract}

Keywords: yogurt, price reduction, brand share, loyalty

\section{Introduction}

Retailers find it rational to temporarily reduce products prices to attract new customers. Although a promotional strategy usually involves two key decisions which are the depth of promotion, and the frequency ${ }^{1}$ of promotion (Allender and Richards, 2012), the objective of retailers from these strategies is to stimulate purchase by providing an incentive (Dawes, 2004). Some studies investigate the differential role of price promotion in driving purchasing behavior and brand choice (Gupta, 1988; Nijs et al., 2001; Pauwels et al., 2002; Hendel and Nevo, 2006). Alvarez and Casielles (2005) show that promotions based on price have the greatest effectiveness on consumers brand choice. Most theoretical models of price reduction assume that search costs make high-search-consumers loyal to a brand (e.g., Salop and Stiglitz, 1977), while other models (e.g., Varian, 1980; Narasimhan, 1988; Lal, 1990) assume that a critical number of buyers have an inherent loyalty to a brand. All these studies assume that loyalty is exogenous to the promotion strategy. Huang et al. (2006) challenges previous assumptions by finding that loyalty is endogenous to the promotion strategy and that the share of loyal consumers in the U.S. orange juice market is largely affected by the frequency of each store's sales.

Though immediate price reduction has been studied extensively in the marketing literature, the relationship between price reduction and consumer behavior, however, is not well addressed. Wood (2006) studied the effect of product type and age on brand selection and brand loyalty respectively. She found that brand selection varies by product category. She also found that the degree of brand loyalty is significantly different for 18-24 year-old consumers. Our study builds on Huang et al. (2006), but extends the analysis by considering almost all brands of yogurt in the U.S. yogurt market to study the effect of price reduction on consumer buying behavior, more specifically the brand choice and the brand

${ }^{1}$ Frequency means average number of times a specific brand is promoted over a specific time period. 
loyalty, and to figure out if the purchasing behavior and loyalty of more popular brands are sensitive to the price promotion of less popular brands. Therefore, the main objective of this study is to test the hypothesis that among price sensitive consumers in the yogurt market, there are some consumers who their choices do not change by the price promotion of less popular brands and they remain loyal to their brands even as other competitive less preferred brands go on price promotion. The contribution of this topic goes to marketers who need to better understand the consumer behavior as is servers as a successful tool for them in meeting their sales objectives.

Yogurt is an interesting case study because it is a very dynamic and fast growing market in the United States. As shown in Figure 1, the per capita consumption of yogurt in the U.S. has increased from 2 (lb/person) in 1975 to 14.4 (lb/person) in 2015. This paper uses the conditional logit model to analyze data that represents the weekly scanner-level purchases of 4200 households from 27 retailers in Eau Claire, Wisconsin and Pittsfield, Massachusetts collected by the Information Resource Inc. (IRI). In the next section, the empirical model is described. Then, we describe the data and define our variables followed by paper's main results. Finally, the conclusion of this study, the study limitations, and suggestion for future research are presented.

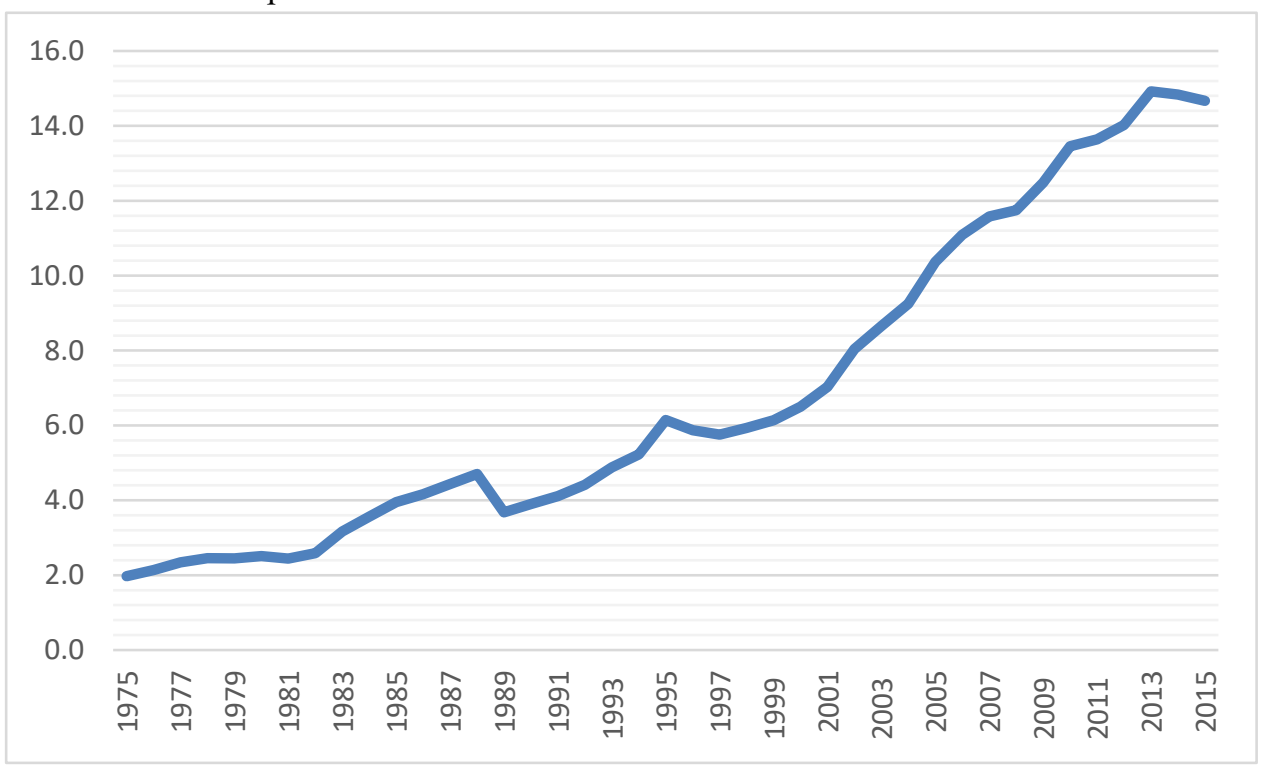

Figure 1. Per Capita Consumption (lb/person) of Yogurt in U.S.

Source: USDA, 2016.

\section{Model}

At the differentiated yogurt market, individuals face different brands to purchase, whether the one they are loyal to, or the one that is offered at a reduced price. Conditional or multinomial logit model is standard in the analysis of discrete choice where outcome variables can take one of several possible values. In this study, the conditional logit procedure is used since it estimates the effects of alternate distinct characteristics on the probability of an individual choosing a given product among different alternatives (Train, 2009). To analyze the discrete choice in the yogurt market, an unordered multinomial model such as conditional logit is appropriate, since there is no clear ordering of the outcome variable (Cameron and Trivedi, 2005) and the data consist of choice-specific attributes that vary across alternatives which are the price and the frequency of price reduction of a given brand in this study.

Let Yi be a random variable that indicates the choice made by consumer $i$, then the conditional logit model (Greene, 2008):

$$
\operatorname{Pr}\left(Y i=j \mid X_{i}\right)=P_{i j}=\frac{\exp \left(U_{i j}\right)}{1+\exp \left(U_{i k}\right)}=\frac{\exp \left(x_{i j}^{\prime} \beta\right)}{\sum_{j=1}^{J} \exp \left(x_{i j}^{\prime} \beta\right)} \quad, \quad j=1,2, \ldots, J
$$

where the $\beta$ are parameters to be estimated; $x_{i j}^{\prime}$ denotes the vector of explanatory variables that determines the choice decision by consumer $i$ of product brand $j$. and consists of the price of a given brand and the percentage of weeks a given brand is on price reduction at a given store. The conditional logit model is estimated with the maximum likelihood estimation (MLE).

Conditional logit model coefficients only provide information about the direction but not the magnitude of the effect of changes in explanatory variables on the probability of choice of brand. Marginal effects of the explanatory variables on 
the probability of choice can be expressed as (Greene, 2008):

$$
\delta_{i j}=\frac{\partial P_{i j}}{\partial x_{i m}}=\left[P_{i j}\left(1(j=m)-P_{i m}\right)\right] \beta \quad, \quad m=1, \ldots, J
$$

Where the marginal effects of each variable on the different alternatives sum up to zero.

\section{Data}

Data used in this study is household weekly scanner-level data of purchases from 27 retailers collected by the Information Resource Inc. (IRI). The data is at the chain level from the city of Eau Claire in Wisconsin and the city of Pittsfield in Massachusetts ${ }^{2}$ for the period 2009-2011. According to IRI, this database consists of a representative panel of about 4200 households who made about 520 thousand purchases during this period. The data provides information for each product at the Universal Product Code (UPC) level, dollar sales, volume sales, retailer, and weeks. Information on product characteristics was obtained from the product category dataset also provided by IRI which contains information on each brand. Using volume equivalent information, unit sales are converted to a product quantity and then retail prices are obtained by dividing the dollar sales on quantities.

To study the two approaches of consumer's behavior, which are the purchasing decision and the brand loyalty, the same explanatory variables are used which are the price and the frequency of price reduction for all brands, but two different dependent variables. For the first approach, the fraction of household that purchase a given brand is used as a dependent variable to analyze the effect of price reduction on the share of households that buy each brand. For the second approach, the brand loyalty is used as a dependent variable to analyze the effect of price reduction on switching behavior of consumers. Following Huang et al. (2006), individuals are defined as loyal consumers if they only bought the specific brand during the observation period. Frequency of price reduction is defined as the percentage of weeks the brand was on price promotion in the specific store. Following Berck et al. (2008), a brand is defined as on price promotion if its weekly price is at least $25 \%$ below the modal price for that brand in that store. After dropping observations with key explanatory variables missing, the sample size was 1,508,690. Summary statistics of main variables used and information about the price promotion activity in the yogurt market are shown in Table 1. Only households that purchased yogurt at least twice during the observation period are included in this study ${ }^{3}$.

Table 1. Summary Statistics of Yogurt Brands’ Prices, Buying, and Price Promotion

\begin{tabular}{|c|c|c|c|c|}
\hline Brands & Mean & Std. Dev. & Min & Max \\
\hline \multicolumn{5}{|l|}{ Prices $(\$ / 6 \mathrm{oz})$} \\
\hline Agro Farma & 1.197 & 0.171 & 0.577 & 1.89 \\
\hline Breyers & 0.844 & 0.236 & 0.28 & 1.59 \\
\hline Danone & 0.723 & 0.248 & 0.195 & 2.98 \\
\hline General Mills & 0.674 & 0.674 & 0.15 & 1.511 \\
\hline H P Hood & 0.455 & 0.108 & 0.186 & 0.79 \\
\hline Lala USA & 0.69 & 0.146 & 0.373 & 1.725 \\
\hline Old Home & 0.58 & 0.112 & 0.168 & 0.89 \\
\hline Other Non-Organic & 1.00 & 0.527 & 0.28 & 2.7 \\
\hline Other Organic & 1.02 & 0.2 & 0.5 & 1.87 \\
\hline $\begin{array}{l}\text { Private Label } \\
\end{array}$ & 0.49 & 0.13 & 0.21 & 1.78 \\
\hline \multicolumn{5}{|l|}{ Week on Price Reduction (\%) } \\
\hline Agro Farma & 3.679 & 2.669 & 0 & 8.633 \\
\hline Breyers & 10.432 & 8.877 & 0 & 33.333 \\
\hline Danone & 9.373 & 6.249 & 0 & 20 \\
\hline General Mills & 12.751 & 8.334 & 0 & 25 \\
\hline H P Hood & 8.515 & 5.404 & 0 & 16.312 \\
\hline Lala USA & 5.009 & 3.620 & 0 & 9.558 \\
\hline Old Home & 5.030 & 3.513 & 0 & 12.605 \\
\hline Other Non-Organic & 4.791 & 3.832 & 0 & 11.765 \\
\hline Other Organic & 3.329 & 2.959 & 0 & 7.92 \\
\hline Private Label & 11.565 & 17.369 & 0 & 45.714 \\
\hline
\end{tabular}

Table 1. Continued

${ }^{2}$ Unfortunately, IRI only provides socioeconomic demographic characteristics of consumers of these two cities.

${ }^{3}$ To check the sensitivity of results, we included only households that purchased yogurt at least twice per year and we found results are robust to this change. 


\begin{tabular}{|c|c|c|c|c|c|}
\hline & Brands & Mean & Std. Dev. & Min & Max \\
\hline \multicolumn{6}{|l|}{ Buying (\%) } \\
\hline & Agro Farma & 17.169 & 23.064 & 0.069 & 100 \\
\hline & Breyers & 12.168 & 17.261 & 0.081 & 100 \\
\hline & Danone & 36.817 & 28.926 & 0.151 & 100 \\
\hline & General Mills & 52.779 & 30.653 & 0.188 & 100 \\
\hline & H P Hood & 15.330 & 18.476 & 0.076 & 100 \\
\hline & Lala USA & 11.355 & 17.685 & 0.069 & 100 \\
\hline & Old Home & 17.017 & 21.779 & 0.127 & 100 \\
\hline & Other Non-Organic & 9.545 & 16.439 & 0.092 & 100 \\
\hline & Other Organic & 6.971 & 12.008 & 0.083 & 100 \\
\hline & Private Label & 15.152 & 20.600 & 0.087 & 100 \\
\hline \multicolumn{6}{|c|}{ Volume on Price Reduction (percent/week) } \\
\hline & Agro Farma & 38.709 & 29.141 & 0 & 100 \\
\hline & Breyers & 43.217 & 28.026 & 0 & 100 \\
\hline & Danone & 36.186 & 20.889 & 0 & 100 \\
\hline & General Mills & 40.322 & 25.426 & 0 & 100 \\
\hline & H P Hood & 45.381 & 29.851 & 0 & 100 \\
\hline & Lala USA & 51.482 & 29.410 & 0 & 100 \\
\hline & Old Home & 39.081 & 23.229 & 0 & 100 \\
\hline & Other Non-Organic & 33.497 & 24.649 & 0 & 100 \\
\hline & Other Organic & 46.733 & 29.861 & 0 & 100 \\
\hline & Private Label & 33.692 & 25.181 & 0 & 100 \\
\hline
\end{tabular}

The model estimation implies the need of using input prices in order to be used as instrumental variables to account for the potential endogeneity of the brand prices. The input prices include the U.S. dry milk price obtained from Federal Milk Marketing Order, corn ${ }^{4}$ price obtained from National Agriculture Statistics Service (NASS), U.S. Department of Agriculture, average hourly earnings in dairy products industry obtained from the U.S. Bureau of Labor Statistics, the average retail price of electricity for industrial use obtained from the U.S. Department of Energy website, and Midwest retail gasoline prices obtained from U.S. Energy Information Administration. Summery statistics of instrumental variables are represented in Table 2. Using two-stage least squares (2SLS) technique, the endogeneity problem of brand prices is fixed first before using in the conditional logit estimation.

Table 2. Input Prices

\begin{tabular}{lllll}
\hline Variable & Mean & Std. Dev. & Min & Max \\
\hline Corn (\$/bushel) & 6.05 & 0.641 & 4.89 & 7.09 \\
Electricity (cents/kilowatt hour) & 7.312 & 0.25 & 7.03 & 7.66 \\
Dry milk (\$/pound) & 1.505 & 0.115 & 1.253 & 1.652 \\
Wages (\$/hour) & 14.53 & 0.297 & 14.01 & 14.92 \\
Gasoline (\$/gallon) & 3.531 & 0.266 & 3.118 & 3.953 \\
\hline
\end{tabular}

\section{Results}

Hosken and Reiffen (2004) show that more popular items are more likely to be on price reduction by retailers. The information on price reduction of brands in Table 1 confirmed that the most popular brands of General Mills and Danone have the highest percentage of weeks on price reduction compared to other yogurt brands. The information on households revealed the fact that the switching behavior is extremely common and brand loyalty is relatively uncommon in the yogurt market. Table 3 shows the percent of brand loyal and switcher households for all brands where the bold numbers represent the percent of loyal consumers who only buy the specific product during years 2009-2011 while the rest represent the percent of households who switch between two brands. From the table, we can notice that General Mills and Danone have the highest percent of loyal consumers in addition to highest percentage of switchers

\footnotetext{
${ }^{4}$ Some brands of yogurt use corn syrup as a sweetener.
} 
while other organic brands have the lowest loyal consumers among brands.

Household income as one of sociodemographic variables may impact consumer behavior. Due to data limitation, as income is provided as a categorial variable rather than the actual value of household income, adding this variable to the model does not capture the variation in consumer behavior. Alternatively, using information on family size, households are divided into low-income and high-income households to find out if the distribution of expenditures on yogurt by low-income households stochastically dominated by the distribution of expenditures on yogurt by high-income households. A test of stochastic dominance is used to compare between these two groups.

The test is conducted over the range of per capita expenditure from zero to $\$ 400$. This range is used to remove problems associated with data outliers. Figure 2 plots the cumulative distribution functions (CDF) for both low-income and high-income households. The CDF for low-income households lies above the CDF of high-income households which reveals that low-income households spend less on yogurt compared to high-income households. The graph shows that $68 \%$ of low-income households spend $\$ 100$ or less per capita compared with only $64 \%$ of high-income households as the gap remains significant at $\$ 100$.

Table 3. Brands Loyal and Switcher Households (\%)

\begin{tabular}{lllllllllll}
\hline Brands & $\begin{array}{l}\text { Agro } \\
\text { Farma }\end{array}$ & Breyers & Danone & $\begin{array}{l}\text { General } \\
\text { Mills }\end{array}$ & $\begin{array}{l}\text { H P } \\
\text { Hood }\end{array}$ & $\begin{array}{l}\text { Lala } \\
\text { USA }\end{array}$ & $\begin{array}{l}\text { Old } \\
\text { Home }\end{array}$ & $\begin{array}{l}\text { Other } \\
\text { Non } \\
\text { Organic }\end{array}$ & $\begin{array}{l}\text { Other } \\
\text { Organic }\end{array}$ & $\begin{array}{l}\text { Private } \\
\text { Label }\end{array}$ \\
\hline Agro Farma & $\mathbf{0 . 4 5}$ & & & & & & & & & \\
Breyers & 12.12 & $\mathbf{0 . 2 5}$ & & & & & & & & \\
Danone & 29.18 & 20.86 & $\mathbf{3 . 8 3}$ & & & & & & & \\
General Mills & 28.67 & 21.34 & 68.51 & $\mathbf{8 . 1 5}$ & & & & & & \\
H P Hood & 5.18 & 2.76 & 19.39 & 21.52 & $\mathbf{0 . 2 7}$ & & & & & \\
Lala USA & 7.97 & 5.36 & 18.26 & 19.12 & 7.99 & $\mathbf{0 . 2}$ & & & & \\
Old Home & 4.67 & 1.78 & 20.21 & 23.85 & 13.37 & 8.15 & $\mathbf{0 . 6 8}$ & & & \\
Other & 13.39 & 9.05 & 23.36 & 23.89 & 7.96 & 7.47 & 8.27 & $\mathbf{0 . 2 9}$ & & \\
Non-Organic & & & & & & & & & & \\
Other Organic & 3.19 & 2.19 & 4.1 & 3.91 & 0.47 & 1.25 & 0.43 & 2.95 & $\mathbf{0 . 0 2}$ & \\
Private Label & 13.15 & 10.42 & 24.3 & 24.2 & 5.14 & 6.47 & 3.89 & 10.18 & 2.37 & $\mathbf{0 . 3 9}$ \\
\hline
\end{tabular}

The Bold numbers are percentage of loyal households and the rest are switchers between two brands.

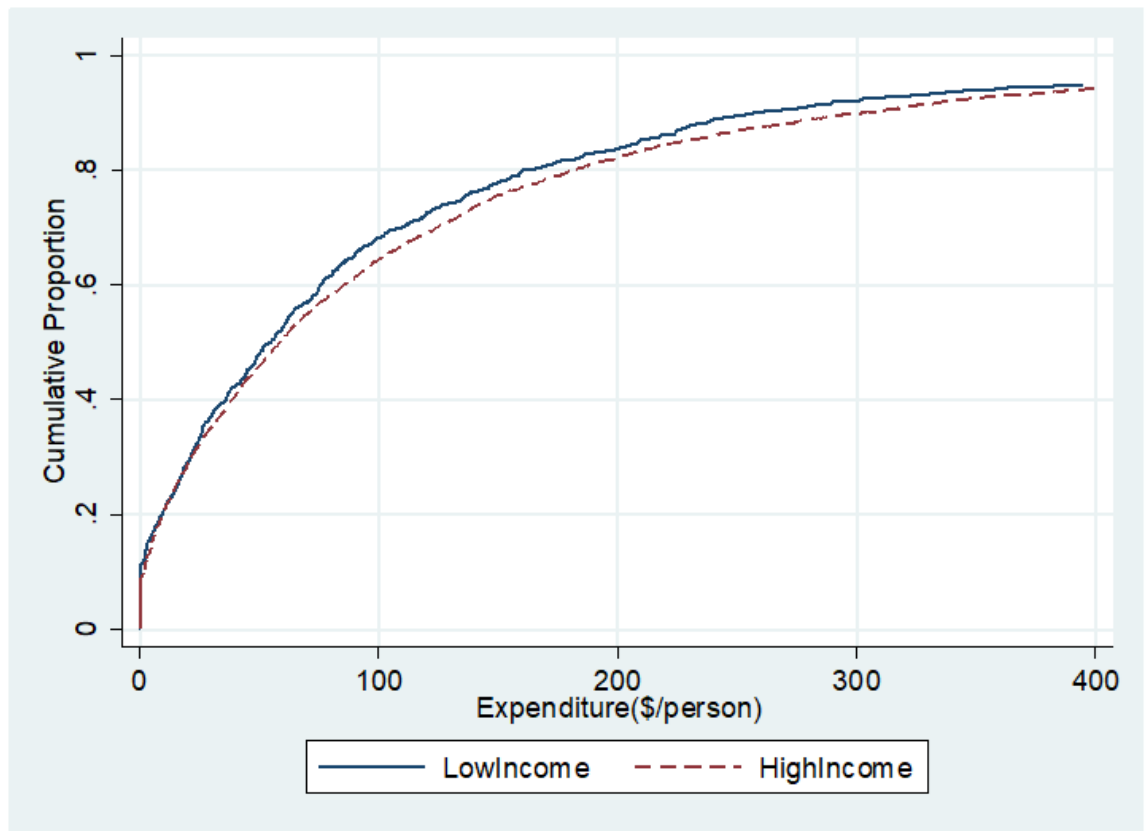

Figure 2. Stochastic Dominance Analysis of Low-Income and High-Income Household Expenditures on Yogurt 


\subsection{Brand Choice}

Based on the overall significance test outcome, i.e., Wald Chi-Square test (Wald chi2 $=11377$ with Prob $>$ chi $2=0.00$ ), the null hypothesis that all of the regression coefficients across all models are simultaneously equal to zero is rejected. In other words, the model provides a good fit of the data and statistically useful for prediction. Table 4 summarizes the conditional logit estimates for main manufacturer brands. Notice that the dependent variable is the fraction of households that purchase the main brands in the market. Other non-organic brands group is considered as a residual category $^{5}$. For all of the explanatory variables, we can reject the null hypothesis that their coefficients do not have an impact on the brand choices where parameters estimated are all significant at 0.01 level.

Table 4. Conditional Logit Estimates for Main Manufacturer Choices

\begin{tabular}{lllll}
\hline $\begin{array}{l}\text { Dependent Variable: } \\
\text { Brand Choice }\end{array}$ & Coef. & Std. Err. & $\mathrm{z}$ & $\mathrm{P}>\mathrm{z}$ \\
\hline Price & -0.717 & 0.010 & -71.92 & 0.00 \\
Promotion & 2.428 & 0.030 & 81.65 & 0.00 \\
\hline Agro Farma & 1.166 & 0.018 & 65.53 & 0.00 \\
Breyers & -0.517 & 0.021 & -24.24 & 0.00 \\
Danone & 1.395 & 0.017 & 79.82 & 0.00 \\
General Mills & 1.491 & 0.018 & 83.35 & 0.00 \\
H P Hood & -1.492 & 0.027 & -54.79 & 0.00 \\
Lala USA & -0.827 & 0.023 & -35.93 & 0.00 \\
Old Home & -0.835 & 0.024 & -35.29 & 0.00 \\
Other Organic & -1.980 & 0.038 & -52.6 & 0.00 \\
Private Label & -0.851 & 0.025 & -34.04 & 0.00 \\
\hline
\end{tabular}

Note: The Other Non-Organic group is the base alternative.

All estimated parameters are statistically significant at 0.01 level.

Conditional logit model coefficients only provide information about the direction but not the magnitude of the effect of changes in explanatory variables on the probability of choice of brand. For example, the negative sign of the parameter estimated related to price indicates that if the price of a brand increases, there is less likely that brand to be purchased by individuals, ceteris paribus. Conversely, the positive sign of the parameter estimated related to price reduction indicates that if the price reduction of a brand increases, there is more likely that brand to be purchased by individuals holding all other variables in the model constant.

Marginal effects of a unit change in explanatory variables and their impact on the household's share of buying each brand holding everything else constant, are illustrated in Table 5. In general, as the price of a brand increases, the fraction of households buying that brand decreases while the percentage of households buying competitor brands increases. For example, a one unit increase in the price of General Mills decreases the probability that households buy General Mills by 0.17 while increases the probability that households buy Danone by 0.09. Similarly, a one unit increase in the price of Agro Farma decreases the probability that households buy Agro Farma by 0.05 while increases the probability that households buy General Mills by 0.02 .

\footnotetext{
5 In this approach, 9 out of 10 models, one for each main brand, are estimated.
} 
Table 5. Marginal Effects for Main Manufacturer Choices

\begin{tabular}{|c|c|c|c|c|c|c|}
\hline \multirow[t]{2}{*}{ Variable } & \multicolumn{2}{|c|}{ Agro Farma } & \multicolumn{2}{|l|}{ Breyers } & \multicolumn{2}{|l|}{ Danone } \\
\hline & $\partial y / \partial x$ & Std. Err. & $\partial y / \partial x$ & Std. Err. & $\partial y / \partial x$ & Std. Err. \\
\hline \multicolumn{7}{|l|}{ Price } \\
\hline Agro Farma & -0.054 & 0.001 & 0.002 & 0.000 & 0.019 & 0.000 \\
\hline Breyers & 0.002 & 0.000 & -0.023 & 0.000 & 0.008 & 0.000 \\
\hline Danone & 0.019 & 0.000 & 0.008 & 0.000 & -0.154 & 0.002 \\
\hline General Mills & 0.023 & 0.000 & 0.009 & 0.000 & 0.089 & 0.001 \\
\hline H P Hood & 0.002 & 0.000 & 0.001 & 0.000 & 0.006 & 0.000 \\
\hline Lala USA & 0.002 & 0.000 & 0.001 & 0.000 & 0.007 & 0.000 \\
\hline Old Home & 0.002 & 0.000 & 0.001 & 0.000 & 0.009 & 0.000 \\
\hline Other Non-Organic & 0.001 & 0.000 & 0.001 & 0.000 & 0.006 & 0.000 \\
\hline Other Organic & 0.000 & 0.000 & 0.000 & 0.000 & 0.001 & 0.000 \\
\hline Private Label & 0.003 & 0.000 & 0.001 & 0.000 & 0.011 & 0.000 \\
\hline \multicolumn{7}{|l|}{ Promotion } \\
\hline Agro Farma & 0.184 & 0.003 & -0.007 & 0.000 & -0.063 & 0.001 \\
\hline Breyers & -0.007 & 0.000 & 0.079 & 0.001 & -0.026 & 0.000 \\
\hline Danone & -0.063 & 0.001 & -0.026 & 0.000 & 0.523 & 0.006 \\
\hline General Mills & -0.079 & 0.001 & -0.032 & 0.001 & -0.300 & 0.004 \\
\hline H P Hood & -0.006 & 0.000 & -0.002 & 0.000 & -0.021 & 0.000 \\
\hline Lala USA & -0.006 & 0.000 & -0.003 & 0.000 & -0.024 & 0.000 \\
\hline Old Home & -0.008 & 0.000 & -0.003 & 0.000 & -0.030 & 0.001 \\
\hline Other Non-Organic & -0.005 & 0.000 & -0.002 & 0.000 & -0.019 & 0.000 \\
\hline Other Organic & -0.001 & 0.000 & 0.000 & 0.000 & -0.004 & 0.000 \\
\hline Private Label & -0.010 & 0.000 & -0.004 & 0.000 & -0.036 & 0.001 \\
\hline
\end{tabular}

The estimated parameters are statistically significant at 0.01 level.

Table 5. Continued

\begin{tabular}{lllllcc}
\hline Variable & \multicolumn{2}{c}{ General Mills } & H P Hood & \multicolumn{2}{c}{ Lala USA } \\
\hline Price & \multicolumn{1}{c}{$\partial \mathrm{y} / \partial \mathrm{x}$} & Std. Err. & $\partial \mathrm{y} / \partial \mathrm{x}$ & Std. Err. & $\partial \mathrm{y} / \partial \mathrm{x}$ & Std. Err. \\
Agro Farma & & & & & & \\
Breyers & 0.023 & 0.000 & 0.002 & 0.000 & 0.002 & 0.000 \\
Danone & 0.009 & 0.000 & 0.001 & 0.000 & 0.001 & 0.000 \\
General Mills & 0.089 & 0.001 & 0.006 & 0.000 & 0.007 & 0.000 \\
H P Hood & -0.171 & 0.002 & 0.008 & 0.000 & 0.009 & 0.000 \\
Lala USA & 0.008 & 0.000 & -0.019 & 0.000 & 0.001 & 0.000 \\
Old Home & 0.009 & 0.000 & 0.001 & 0.000 & -0.022 & 0.000 \\
Other Non-Organic & 0.011 & 0.000 & 0.001 & 0.000 & 0.001 & 0.000 \\
Other Organic & 0.007 & 0.000 & 0.000 & 0.000 & 0.001 & 0.000 \\
Private Label & 0.002 & 0.000 & 0.000 & 0.000 & 0.000 & 0.000 \\
\hline Promotion & 0.013 & 0.000 & 0.001 & 0.000 & 0.001 & 0.000 \\
Agro Farma & & & & & \\
Breyers & -0.079 & 0.001 & -0.006 & 0.000 & -0.006 & 0.000 \\
Danone & -0.032 & 0.001 & -0.002 & 0.000 & -0.003 & 0.000 \\
General Mills & -0.300 & 0.004 & -0.021 & 0.000 & -0.024 & 0.000 \\
H P Hood & 0.580 & 0.007 & -0.026 & 0.001 & -0.030 & 0.001 \\
Lala USA & -0.026 & 0.001 & 0.065 & 0.001 & -0.002 & 0.000 \\
Old Home & -0.030 & 0.001 & -0.002 & 0.000 & 0.073 & 0.001 \\
Other Non-Organic & -0.038 & 0.001 & -0.003 & 0.000 & -0.003 & 0.000 \\
Other Organic & -0.024 & 0.000 & -0.002 & 0.000 & -0.002 & 0.000 \\
Private Label & -0.005 & 0.000 & 0.000 & 0.000 & 0.000 & 0.000 \\
\hline The & -0.045 & 0.001 & -0.003 & 0.000 & -0.004 & 0.000 \\
\hline
\end{tabular}

The estimated parameters are statistically significant at 0.01 level. 
Table 5. Continued

\begin{tabular}{lllll}
\hline Variable & \multicolumn{3}{c}{ Old Home } & \multicolumn{2}{c}{ Other Non-Organic } \\
\hline & \multicolumn{1}{c}{$\partial \mathrm{y} / \partial \mathrm{x}$} & Std. Err. & \multicolumn{2}{c}{ Std. Err. } \\
\hline Price & & & & \\
Agro Farma & 0.002 & 0.000 & 0.001 & 0.000 \\
Breyers & 0.001 & 0.000 & 0.006 & 0.000 \\
Danone & 0.009 & 0.000 & 0.007 & 0.000 \\
General Mills & 0.011 & 0.000 & 0.000 & 0.000 \\
H P Hood & 0.001 & 0.000 & 0.001 & 0.000 \\
Lala USA & 0.001 & 0.000 & 0.001 & 0.000 \\
Old Home & -0.027 & 0.001 & -0.017 & 0.000 \\
Other Non-Organic & 0.001 & 0.000 & 0.000 & 0.000 \\
Other Organic & 0.000 & 0.000 & 0.001 & 0.000 \\
Private Label & 0.001 & 0.000 & & \\
Promotion & & & -0.005 & 0.000 \\
Agro Farma & -0.008 & 0.000 & -0.002 & 0.000 \\
Breyers & -0.003 & 0.000 & -0.019 & 0.000 \\
Danone & -0.030 & 0.001 & -0.024 & 0.000 \\
General Mills & -0.038 & 0.001 & -0.002 & 0.000 \\
H P Hood & -0.003 & 0.000 & -0.002 & 0.000 \\
Lala USA & -0.003 & 0.000 & -0.002 & 0.000 \\
Old Home & 0.093 & 0.002 & 0.059 & 0.001 \\
Other Non-Organic & -0.002 & 0.000 & 0.000 & 0.000 \\
Other Organic & -0.001 & 0.000 & -0.003 & 0.000 \\
Private Label & -0.005 & 0.000 & &
\end{tabular}

The estimated parameters are statistically significant at 0.01 level.

Table 5. Continued

\begin{tabular}{lllll}
\hline Variable & Other Organic & & \multicolumn{2}{c}{ Private Label } \\
\hline Price & $\partial \mathrm{y} / \partial \mathrm{x}$ & Std. Err. & \multicolumn{2}{c}{ Std. Exr. } \\
Agro Farma & 0.0003 & 0.0000 & 0.0028 & 0.0001 \\
Breyers & 0.0001 & 0.0000 & 0.0011 & 0.0000 \\
Danone & 0.0012 & 0.0000 & 0.0107 & 0.0002 \\
General Mills & 0.0015 & 0.0001 & 0.0134 & 0.0002 \\
H P Hood & 0.0001 & 0.0000 & 0.0009 & 0.0000 \\
Lala USA & 0.0001 & 0.0000 & 0.0011 & 0.0000 \\
Old Home & 0.0002 & 0.0000 & 0.0014 & 0.0000 \\
Other Non-Organic & 0.0001 & 0.0000 & 0.0009 & 0.0000 \\
Other Organic & -0.0039 & 0.0001 & 0.0002 & 0.0000 \\
Private Label & 0.0002 & 0.0000 & -0.0324 & 0.0006 \\
\hline Promotion & & & \\
Agro Farma & -0.0011 & 0.0000 & -0.0095 & 0.0002 \\
Breyers & -0.0004 & 0.0000 & -0.0039 & 0.0001 \\
Danone & -0.0042 & 0.0002 & -0.0362 & 0.0006 \\
General Mills & -0.0052 & 0.0002 & -0.0454 & 0.0008 \\
H P Hood & -0.0004 & 0.0000 & -0.0032 & 0.0001 \\
Lala USA & -0.0004 & 0.0000 & -0.0036 & 0.0001 \\
Old Home & -0.0005 & 0.0000 & -0.0046 & 0.0001 \\
Other Non-Organic & -0.0003 & 0.0000 & -0.0029 & 0.0001 \\
Other Organic & 0.0133 & 0.0005 & -0.0006 & 0.0000 \\
Private Label & -0.0006 & 0.0000 & 0.1099 & 0.0018 \\
\hline
\end{tabular}

The estimated parameters are statistically significant at 0.01 level.

As the frequency of price reduction increases for a brand, despite the popularity of a brand, the fraction of households buying that brand increases while the percentage of households buying other brands decreases. For the main brand in the market, a one percent increase in the price reduction of General Mills increases the probability that households buy General Mills by 0.58 while decreases the probability of households buy Danone by 0.3 . The negative impact of price 
reduction for a given brand on the brand choice of competitor brands does not limited only to main brands in the market since brands with the low market share can also have a negative impact on the share of households buying main brands as they go on price reduction. For example, one percent increase in the frequency of price reduction of H P Hood increases the probability that households buying $\mathrm{H}$ P Hood by 0.06 while decreases the probability that households buy each of Agro Farma, Danone, and General Mills by 0.01, 0.02, and 0.03, respectively.

\subsection{Brand Loyalty}

For the brand loyalty analysis, the focus is only on General Mills and Danone, and all other brands are grouped in one category. In the yogurt market, switching behavior is very common where most households switch between brands in response to the price reduction and very few of them remain loyal to a specific brand. General Mills and Danone which collectively accounted for about 75 percent of the yogurt market share, have collectively only 12 percent of loyal consumers. Based on the overall significance test outcome, i.e., Wald Chi-Square test (Wald chi2 $=264$ with Prob > chi $2=0.00$ ), the null hypothesis that all of the regression coefficients across all models are simultaneously equal to zero is rejected. In other words, the model provides a good fit of the data and statistically useful for prediction. Notice that the dependent variable is the fraction of households who are loyal to the considered brands. Other brands group is considered as a residual category. Table 6 shows the conditional logit results for the effect of the price and the frequency of price reduction on the brand loyalty in the yogurt market. For all of the explanatory variables, we can reject the null hypothesis that their coefficients do not have an impact on the brand loyalty where parameters estimated are all significant at 0.01 level.

Table 6. Conditional Logit Estimates for Main Manufacturer Loyalty

\begin{tabular}{lllll}
\hline $\begin{array}{l}\text { Dependent Variable: } \\
\text { Brand Loyalty }\end{array}$ & Coef. & Std. Err. & $\mathrm{Z}$ & $\mathrm{P}>\mathrm{Z}$ \\
\hline Price & & & & \\
Promotion & -0.385 & 0.081 & -4.75 & 0.00 \\
\hline Danone & 3.112 & 0.193 & 16.12 & 0.00 \\
General Mills & 0.178 & 0.053 & 3.39 & 0.001 \\
\hline
\end{tabular}

Note: The Other group is the base alternative.

All estimated parameters are statistically significant at 0.01 level.

Similar as above, the negative sign of the parameter estimated related to price indicates that if the price of a brand increases, there is less likely that individuals remain loyal to that brand, ceteris paribus. Conversely, the positive sign of the parameter estimated related to price reduction indicates that if the price reduction of a brand increases, there is more likely that households remain loyal to that brand holding all other variables in the model constant.

Table 7 shows the marginal effects for the brand loyalty estimation. In general, a one unit increase in the price of a brand decreases the probability that individuals remain loyal to that brand and increase the probability that individuals remain loyal to competitor brands. For example, a unit increase in the price of Danone decreases the probability of Danone loyalty by 0.08 and increases the probability of General Mills loyalty by 0.06 . Conversely to the effect of price, a unit increase in the frequency of price reduction for a given brand increases the probability of its brand loyalty and decreases the probability of other competitor brands loyalty. A unit increase in the frequency of price reduction of Danone will increase the probability that households remain loyal to Danone by 0.67 while decreases the probability that households remain loyal to General Mills by 0.5 . A unit increase in the price reduction of other non-popular brands will increases the probability that households remain loyal to those brands by 0.44 while decreases the probability that households remain loyal to popular brands of Danone and General Mills by 0.17 and 0.28 , respectively.

Table 7. Marginal Effect Estimates for Main Manufacturer Loyalty

\begin{tabular}{lllllll}
\hline Variable & $\begin{array}{c}\text { Danone } \\
\partial \mathrm{y} / \partial \mathrm{x}\end{array}$ & Std. Err. & $\begin{array}{c}\text { General Mills } \\
\partial \mathrm{y} / \partial \mathrm{x}\end{array}$ & Std. Err. & $\begin{array}{c}\text { Other } \\
\partial \mathrm{y} / \partial \mathrm{x}\end{array}$ & Std. Err. \\
\hline Price & -0.083 & 0.017 & 0.062 & 0.013 & 0.021 & 0.004 \\
$\quad$ Danone & 0.062 & 0.013 & -0.096 & 0.020 & 0.034 & 0.007 \\
$\quad$ General Mills & 0.021 & 0.004 & 0.034 & 0.007 & -0.055 & 0.012 \\
$\quad$ Other & & & & & \\
Promotion & 0.671 & 0.042 & -0.502 & 0.032 & -0.169 & 0.011 \\
$\quad$ Danone & -0.502 & 0.032 & 0.778 & 0.048 & -0.275 & 0.019 \\
$\quad$ General Mills & -0.169 & 0.011 & -0.275 & 0.019 & 0.444 & 0.030 \\
$\quad$ Other & & & & & & \\
\hline
\end{tabular}

The estimated parameters are statistically significant at 0.01 level. 


\section{Conclusion}

Using scanner-level data from the yogurt market, this study estimated the likelihood that households buy a specific brand and also remain loyal to a given brand of yogurt in the presence of a store's price promotion. Results show that, in general, an increase in the frequency of price reduction for a given brand increases the probability that households buy that brand and decreases the probability that households buy competitive brands despite the popularity of a given brand. In the same way, an increase in the frequency of price reduction for a given brand increases the probability that households remain loyal to that brand and decreases the probability that households remain loyal to other competitive brands even if the reduced price brand is not a popular one. In other words, there is a strong evidence to support the hypotheses that the choice of high preferred brands and their brand loyalty are sensitive to the price promotion of less preferred brands.

Aggregation across brands is considered to be one of the limitations of this study where it is not necessary for all different flavors of a given brand to be on price reduction by a given retailer in a specific week. The bottom part of Table 1 shows the volume of price reduction for all brands that identifies the percentage of different flavors of a given brand on price reduction in a week. As a result, it is not easy to decide whether a specific brand is on price promotion by a retailer in a specific week. There is also a data limitation where there is no available information if the purchased product was on price promotion. Whether the product was on price promotion or not depends on the researchers' definition of price promotion activity where in this study a product is defined as on price promotion if its weekly price is at least $25 \%$ below the modal price for that product in that store. In such a case, results will be sensitive to the researchers' definition of price promotion.

\section{Acknowledgements}

The authors acknowledge the department of Agricultural and Applied Economics at Texas Tech University for their support. We thank audiences of the $39^{\text {th }}$ Annual ISMS Marketing Science Conference in Los Angeles, California, in 2017 for their comments that improved earlier version of this work. Also, we thank Dr. Benaissa Chidmi at Texas Tech University for his valuable comments which improved the quality of the paper. Finally, the authors thank the editor and two anonymous reviewers of this journal for their helpful comments and suggestions. Any remaining errors are solely the responsibility of the authors.

\section{References}

Allender, W. J., \& Richards, T. J. (2012). Brand Loyalty and Price Promotion Strategies: An Empirical Analysis. Journal of Retailing, 88(3), 323-342. https://doi.org/10.1016/j.jretai.2012.01.001

Alvarez, B. A., \& Casielles, R. V. (2005). Consumer Evaluations of Sales Promotion: The Effect on Brand Choice. European Journal of Marketing, 39(1/2), 54-70. https://doi.org/10.1108/03090560510572016

Berck, P., Brown, J., Perloff, J. M., \& Villas-Boas, S. B. (2008). Sales: Tests of Theories on Causality and Timing. International Journal of Industrial Organization, 26, 1257-1273. https://doi.org/10.1016/j.ijindorg.2007.12.007

Cameron, A. C., \& Trivedi, P. K. (2005). Microeconomics: Methods and Applications. Cambridge University Press, Cambridge, UK.

Dawes, J. (2004). Assessing the Impact of a Very Successful Price Promotion on Brand, Category and Competitor Sales. Journal of Product and Brand Management, 13(5), 303-314. https://doi.org/10.1108/10610420410554395

Greene, W. H. (2008). Econometric Analysis. Sixth Edition, Pearson Prentice Hall, New Jersey, USA.

Gupta, S. (1988). Impact of Sales Promotions on When, What, and How Much to Buy. Journal of Marketing Research, $25,342-355$

Hendel, B. I., \& Nevo, A. (2006). Measuring the Implications of Sales and Consumer Inventory Behavior. Econometrica, 74(6), 1637-1673. http://dx.doi.org/10.3386/w11307

Hosken, D., \& Reiffen, D. (2004). Multiproduct Retailers and the Sale Phenomenon. Agribusiness, 17(1), 115-137. https://doi-org.lib-e2.lib.ttu.edu/10.1002/1520-6297(200124)17:1<115::AID-AGR1006>3.0.CO;2-H

Huang, R., Perloff, J. M. \& Villas-Boas, S. B. (2006). Effect of Sales on Brand Loyalty. Journal of Agricultural \& Food Industrial Organization, 4, 1-24.

Lal, R. (1990). Price Promotions: Limiting Competitive Encroachment. Marketing Science, 9(3), 247-262. http://doi.org10.1287/mksc.9.3.247

Narasimhan, C. (1988). Competitive Promotional Strategies. The Journal of Business, 61(4), 427-449.

Nijs, V. R., Dekimpe, M. G., Steenkamp J.-B. E. M., \& Hanssens, D. M. (2001). The Category Demand Effects of Price Promotions. Marketing Science, 20(1), 1-22. https://doi.org/10.1287/mksc.20.1.1.10197 
Pauwels, K., Hanssens, D. M., \& Siddarth, S. (2002). The Long-Term Effects of Price Promotions on Category Incidence, Brand Choice and Purchase Quantity. Journal of Marketing Research, 39, 421-439.

Salop, S., \& Stiglitz, J. (1977). Bargains and Ripoffs: A Model of Monopolistically Competitive Price Dispersion. Review of Economic Studies, 44(3), 493-510.

Train, K. E. (2009). Discrete Choice Methods with Simulation. Cambridge University Press. Cambridge, UK.

Varian, H. (1980). A Model of Sales. The American Economic Review, 70(4), 651-659.

Wood, L. M. (2006). Dimensions of Brand Purchasing Behaviour: Consumers in the 18-24 Age Group. Journal of Consumer Behaviour, 4(1), 9-24. https://doi-org.lib-e2.lib.ttu.edu/10.1002/cb.154

\section{Copyrights}

Copyright for this article is retained by the author(s), with first publication rights granted to the journal.

This is an open-access article distributed under the terms and conditions of the Creative Commons Attribution license which permits unrestricted use, distribution, and reproduction in any medium, provided the original work is properly cited. 